JP3I (Jurnal Pengukuran Psikologi dan Pendidikan Indonesia), I0(2), 202I, II8-132

D0l: http://dx.doi.org/I0.15408/jp3i.v10i2.19777

http://journal.uinjkt.ac.id/index.php/jp3i

\title{
Confirmatory Factor Analysis of the Academic Self-Efficacy Scale: An Indonesian Version
}

\author{
Kusumasari Kartika Hima Darmayanti ${ }^{1}$, Erlina Anggraini ${ }^{2}$, Efan Yudha Winata ${ }^{3}$, \\ M. Fariz Fadillah Mardianto ${ }^{4}$
}

Department of Educational Psychology, Faculty of Psychology, Universitas Islam Negeri Raden Fatah Palembang, Indonesia ${ }^{1}$

School of Psychology, Northeast Normal University, China ${ }^{2}$

Faculty of Psychology, Universitas Teknologi Sumbawa, Indonesia ${ }^{3}$

Department of Mathematics, Universitas Airlangga, Indonesia ${ }^{4}$

kusumasarikhd@gmail.com

\begin{abstract}
Several studies regarding academic self-efficacy are developed in which a valid and reliable measurement is needed. One of the well-known instruments used to measure college students' academic self-efficacy is The Academic Self-Efficacy Scale (TASES). It was designed by Sagone and Caroli (2014), comprising four dimensions, i.e., self-engagement, self-oriented decision-making, others-oriented problem-solving, and interpersonal climate. This instrument contained 30 items at first, but two items were removed after testing the factor analysis, and 28 items remained. This study examined the validity of the adaptation of TASES into the Indonesian version. This scale was adapted into the Indonesian version using confirmatory factor analysis (CFA), involving 166 Indonesian college students studying at universities in Indonesia and abroad. The CFA results showed that the items which were distributed in 4 dimensions in this scale are found to fit except three items of interpersonal climate dimension. Therefore those three items have been eliminated. In addition, the coefficient of Cronbach's Alpha of TASES Indonesian version is highly reliable. Ultimately, the TASES Indonesian version consisting of 25-item within four dimensions has shown to be a reliable and valid measurement for academic self-efficacy in the Indonesian context.
\end{abstract}

Keywords: Confirmatory factor analysis, validation, academic self-efficacy, college students, Indonesian version.

\begin{abstract}
Abstrak
Beberapa penelitian mengenai academic self-efficacy telah dikembangkan dan membutuhkan alat ukur yang valid dan reliabel. Salah satu alat ukur yang terkenal untuk digunakan mengukur academic self-efficacy mahasiswa ialah The Academic Self-Efficacy Scale (TASES). Alat ukur ini dirancang oleh Sagone dan Caroli (2014) yang terdiri dari empat dimensi, yaitu: self-engagement, self-oriented decision-making, others-oriented problem-solving, dan interpersonal climate. Alat ukur ini pada awalnya terdiri dari 30 item, namun setelah dilakukan uji analisis faktor, dua item dihilangkan, tersisa 28 item. Penelitian ini mengkaji validasi adaptasi TASES pada versi Indonesia. Alat ukur ini diadaptasi dalam versi Indonesia menggunakan Confirmatory Factor Analysis (CFA) yang melibatkan 166 mahasiswa Indonesia yang belajar di universitas di Indonesia dan luar negeri. Hasil CFA menunjukkan bahwa item-item yang terdistribusi pada empat dimensi dalam skala ini ditemukan fit kecuali tiga item pada dimensi interpersonal climate, oleh karena itu tiga item tersebut dihilangkan. Selain itu, koefisien Cronbach's Alpha dari TASES versi Indonesia sangat reliabel. Terakhir, TASES versi Indonesia yang terdiri dari 25 item dalam empat dimensi telah terbukti menjadi ukuran yang reliabel dan valid untuk mengukur academic self-efficacy dalam konteks Indonesia.
\end{abstract}

Kata Kunci: Confirmatory factor analysis, validasi, academic self-efficacy, mahasiswa, versi Indonesia. 


\section{Introduction}

First-year undergraduate students often experience tension, at least moderate stress, because the academic pressure between university and secondary school is quite different (Pierceall \& Keim, 2007). Freshmen students who have poor coping skills and are difficulty adjusting to the academic environment often encounter stress, low level of well-being, depression, anxiety, and even dropout (Garett et al., 2017; Sharma \& Wavare, 2013; Owens, Stevenson, Hadwin, 2012; Stinebrickner \& Stine, 2012).

A similar condition related to students' responses to the current academic situation was reported by Maulida, 2012. Maulida (2012) revealed that some students in Universitas Indonesia admitted to being depressed, characterized by cheerlessness or losing interest, worthless, frustrated, hopeless, and they also had suicidal thoughts. The data were obtained from a counseling service unit for college students in Universitas Indonesia (Badan Konseling Mahasiswa Universitas Indonesia) (Maulida, 2012). Furthermore, the Ministry of Research, Technology, and Higher Education (Kemenristek) of the Republic of Indonesia informed that in 2017 out of 6,924,511 enrolled students in state universities and private universities in Indonesia, 195,176 students (2.8\%) dropped out (Talar \& Gozaly, 2020). From those numbers, the percentage of dropout students in private universities was higher than in public universities, $4 \%$ and $0.3 \%$, respectively (Talar \& Gozaly, 2020).

The above cases result from a low sense of academic self-efficacy of the students (Preiss, Gayle \& Allen, 2006; Richardson, Abraham \& Bond, 2012; Robbins et al., 2004). Conversely, students with a higher level of academic self-efficacy believe that they are more capable of meeting challenges at school, tend to be more motivated, use more strategies (such as self-regulated learning), have greater achievement, and feel less tension and anxiety (Morton et al., 2014; Barrey \& Finney, 2009). Therefore, they can easily adjust to the academic climate and socio-academic climate that influence their academic achievements.

The concept of academic self-efficacy referred to the concept of self-efficacy by psychologist Albert Bandura $(1977,1986)$. Albert Bandura $(1977,1986,1997)$ has defined self-efficacy as one's belief in one's ability to succeed or accomplish a task in a particular situation and learn or perform behavior at designated levels. In the academic context, Schunk (1991) stated that self-efficacy is a person's belief that they can complete academic tasks successfully (e.g., taking notes, asking questions, etc.).

Putwain et al. (2013) reported that academic self-efficacy could predict future academic performance in a university setting and predict learning-related emotions through academic performance. $\mathrm{Li}$ (2012) showed that the higher academic self-efficacy students have the more effort students put into the subject. Further, academic self-efficacy and academic achievement are also positively correlated (Li, 2012). Morton et al. (2014) demonstrated that a high level of self-efficacy will experience life with less stress in the first year in university.

\section{Description of The Academic Self-Efficacy Scale (TASES)}

This present study was conducted to examine The Academic Self-Efficacy Scale (TASES) designed by Sagone and Caroli (2014) using confirmatory factor analysis (CFA). This scale measured the perceived selfefficacy in the academic context and included 30 items, each value on a 7-point Likert scale ranging from 1 (not at all efficient) to 7 (completely efficient). In addition, it contained four dimensions: self-engagement, self-oriented decision-making, others-oriented problem solving, and interpersonal climate (Sagone \& Caroli, 2014).

The first dimension of TASES (self-engagement) refers to the ability to resolve personal engagement difficulties. The second dimension (self-oriented decision making) refers to the ability to find solutions using themselves as a source aid. The third dimension (others-oriented problem solving) refers to the skill to solve 
critical problems by using other people to support, and the last dimension (interpersonal climate) is the ability to create a prosocial and collaborative climate in interpersonal relationships (Sagone \& Caroli, 2014).

Several scales have been developed to measure academic self-efficacy, such as College Self-Efficacy Inventory (CSEI; Solberg et al., 1993), Patterns of Adaptive Learning Scales (PALS; Midgley et al., 2000), Self-Efficacy Questionnaire for Children (SEQ-C; Muris, 2001), and Academic Behavioral Confidence (ABC; Sanders \& Sanders, 2009).

\section{CSEI (College Self-Efficacy Inventory)}

Solberg et al. (1993) constructed CSEI (College Self-Efficacy Inventory) to measure college students' selfefficacy associated with academic achievements. It was proposed to understand the role of self-efficacy of Hispanic college students in the process of college adjustment in the United States (Solberg et al., 1993).

CSEI consisted of 20 items with a 10-point Likert scale to rate the confidence. The higher point indicated the higher confidence to complete the task related to the college (Gore, 2006; Solberg et al., 1993). In addition, CSEI contained three categories: course self-efficacy ( 7 items), roommate self-efficacy (4 items), and social self-efficacy (9 items) (Gore, 2006; Solberg et al., 1993).

\section{PALS (Patterns of Adaptive Learning Scales)}

Midgley et al. (2000) demonstrated that patterns of adaptive learning scales (PALS) were designed in educational settings to understand the correlation between learning environment and students' motivation, affect, and behavior. PALS for students consisted of 94 items within five broad components such as personal achievement goal orientation, perceptions of teacher's goal, perceptions of the goal structures in the classroom, achievement-related belief, attitude, and strategies, and perception of parents and home life (Midgley et al., 2000). This scale used a 5-point Likert scale ranging from 1 (not at all true), 3 (somewhat true), and 5 (very true) (Midgley et al., 2000).

While PALS for teachers consisted of 29 items, it evaluated teacher's perception of the goal structure in the school, goal-related approaches to instruction, personal teaching efficacy and also used a 5-point Likert scale ranging from 1 (strongly disagree), 3 (somewhat agree), and 5 (strongly agree) (Midgley et al., 2000).

\section{SEQ-C (Self-Efficacy Questionnaire for Children)}

According to social-cognitive theory by Albert Bandura, Muris developed a self-efficacy questionnaire for children (SEQ-C) to measure the conviction of youth regarding their social, academic, and emotional domains (Muris, 2001). This scale was developed in the Netherlands, and the sample was limited to European youths aged 14-17 years old. It consisted of 24 items ranging from 1 (not at all) to 5 (very well). SEQ-C scores are associated with a measure of depression in a potentially significant manner. It can be seen that the lower the SEQ-C scores of the youths mean the greater level of their depression (Muris, 2001).

\section{ABC (Academic Behavioural Confidence)}

Sander and Sanders (2009) demonstrated that the Academic Behavioural Confidence (ABC) was designed to provide a global measure of academic confidence, and it can be beneficial for teachers in understanding their students and in knowing students' achievement levels (Sander \& Sanders, 2009). ABC consisted of 24 items and each of which respondents rated on a 5-point Likert scale. This scale may arise from four basic concepts of self-efficacy: mastery experience, vicarious experience, verbal persuasion, and physiological states (Bandura 1977, 1986, 1993).

No study has adapted the academic self-efficacy scale (TASES) developed by Sagone and Caroli (2014) into the Indonesian version. The academic self-efficacy scale (TASES) was used in the current study to 
investigate the perceived self-efficacy of first-year college students in an educational context in Indonesia. It is a critical step since an instrument's adaptation has a cultural fit to be used in various cultural contexts (Borsa et al., 2012). Furthermore, several studies have reported that language and cognition have a tight relationship. For example, King (2017) and Lupyan and Lewis (2019) reported that language impacts the cognitive structure and semantic knowledge. Furthermore, language can influence and shape one's thoughts, decision-making, and strategy for solving crucial problems (Gleitman \& Papafragou, 2012; Novack \& Goldin-Meadow, 2015).

Thus, adapting an existing instrument is needed to measure data from different samples, backgrounds, and even languages through several steps that provide greater fairness in the assessment (Borsa et al., 2012). Therefore, this present study attempted to validate the adaptation of TASES into the Indonesian version using confirmatory factor analysis (CFA) to assess the academic self-efficacy of Indonesian college students.

\section{Methods}

The adaptation process in this study referred to Beaton et al. (2000) that contained six essential stages: [1] Instrument translation from the original version into the Indonesian language; [2] Synthesis of the translated version from translators; [3] Back translation conducted by translators; [4] Expert committee (e.g., researchers, lecturers, or academic self-efficacy experts); [5] Test of the pre-final Indonesian version; and [6] Submission of documentation to the developers or coordinating committee for appraisal of the adaptation process.

Instrument translation into Indonesian version. Three translators conducted the translation process. The first and second translators are those who understand the concept of the academic self-efficacy scale and are English experts. The third translator is an English specialist but has less knowledge of the scale.

Synthesis of the translated version. Researchers held a conversation with the translators after translating the instrument. Each of the issues in the translation results was discussed, and problems were resolved.

Back translation. After synthesizing the instrument, the scale was retranslated into the English version. In this process, two students in one of the colleges in Australia were involved. This validity testing method ensures that the translated version represents the exact item content as the original one. Furthermore, this stage is fruitful in controlling the validity and identifying major inconsistencies and conceptual errors in the translation (Beaton et al., 2000).

Expert committee (researchers, lecturers, or academic self-efficacy experts). Peer judgment and expert judgment were needed in this step. In this process, peer judgment includes two people, both researchers, and lecturers in the Faculty of Psychology at one of the universities in Indonesia. Additionally, the expert judgment involves a researcher and a lecturer in the Faculty of Psychology who has a better understanding of the concept of academic self-efficacy and has been publishing academic papers about academic selfefficacy.

Peer judgment and expert judgment have reviewed the scale's translation, synthesis, and backtranslation. Some critical points need to be noted, which are: semantic equivalence, after translation, synthesis, and back-translation have been completed, each item should have the same semantic meaning as the original version. Idiomatic equivalence, idioms are typically difficult to translate since they are based on the cultural context of the original developers. Consequently, the appropriate expression in the Indonesian version should be formulated by the committee. Experiential equivalence, each country has different daily life experiences, so each item of the instrument should be replaced by a comparable item that is currently practiced in Indonesian culture. Conceptual Equivalence, distinct conceptual meanings are often found among 
cultures. The committee should investigate and examine the words on each item in the original version and back translation and how other words would work on it.

Test of the pre-final Indonesian version. This part consisted of the psychometric process. We split this part into some points:

Participants. A total of 166 college students participated in this study who studied in Indonesia, Australia, Japan, United Kingdom, Saudi Arabia, Germany, Sweden, Belgium, United State, Netherland, Malaysia, and France. The participants were diverse in term of educational levels with diploma $(n=3 ; 1.8 \%)$, undergraduate $(n=25 ; 15.1 \%)$, master programme $(n=108 ; 65.1 \%)$, and doctoral programme $(n=30$; $18.1 \%)$; gender $(n=98 ; 59 \%)$ for female and $(n=68 ; 41 \%)$ for male; country of study $(n=123 ; 74.1 \%)$ studying in Indonesia and $(n=43 ; 25.9 \%)$ studying abroad.

Procedure. After considering the modifications suggested by the experts and receiving informed consent letters from the participants, researchers assessed the Indonesian version of the academic self-efficacy scale (TASES). The participants were collected through convenience sampling (Cozby \& Bates, 2015; Gravetter \& Forzano, 2018). Google Form was distributed to the target participants through social media such as WhatsApp, Facebook, and Instagram.

Data Analysis. TASES was constructed by Sagone and Caroli (2014) to measure the academic selfefficacy of college students based on the self-efficacy theory of Albert Bandura. It consisted of 30-item within four dimensions. After validating the instrument using an analysis factor approach, 28-item left within four dimensions. Those four dimensions are self-engagement, self-oriented decision making, others-oriented problem solving, and interpersonal climate (Sagone \& Caroli, 2014).

In detail, each of the dimensions consists of 7 items. The dimension of self-engagement is in item 1, 2 , $6,7,9,16$, and 23; Self-oriented decision-making in item number 3, 13, 17, 18, 20, 21, and 22; Othersoriented problem-solving dimension has been allocated in item number 4, 8, 10,11, 14, 27, and 28; While, interpersonal climate dimension is in item number 5, 12, 15, 24, 26, 19, and 25. However, item number 24 is unfavorable in direction ranging from $(1=$ very sure $)$ to $(4=$ not sure at all).

TASES is a self-report scale using a 4-point Likert scale. The original Likert-type scale of this instrument was 7-point. Yet, it changed into a 4-point Likert scale after the peer judgment process to minimize the participants' neutral response option.

Construct validity has been used in this present study to examine the validity (Cohen et al., 2013) with analysis factor (confirmatory factor analysis/CFA; Cohen et al., 2013). To analyze with CFA, the researchers used structural equation modeling (SEM) with $\mathrm{R}$ application 4.0.2 version (2020-06-22) in which Lavaan 0.6-6 version has been installed. In order to answer the research questions of this study, TASES is indicated fit when the values meet the criteria as follow: CFI $>.95$, RMSEA $<.06$, SRMR $<.08$, $\mathrm{TLI} \geq .95$ (Hu \& Bentler, 1999). However, the Chi-Square index $\left(\mathrm{c}^{2}\right)$ has not been reported due to its sensitivity to the sample size (Lacobucci, 2010; Brown, 2015; Little, 2013). On the other hand, the items should be eliminated based on the factor loading value (1) $£$.32 (Tabachnick \& Fidell, 2007). Lastly, AIC (Akaike Information Criterion) is also reported indicating that smaller values are better for comparing the model (Yamin \& Kurniawan, 2009; Akaike, 1974).

Reliability test was performed by comparing the coefficient of Cronbach alpha (Cohen et al., 2013) with the coefficient alpha ranging from .70 to .90 and indicating a high-reliability score (Hinton et al., 2004). In other words, the coefficient alpha value is above .70 (Bland \& Altman, 1997). In this present study, IBM SPSS 24 version has been used to test the reliability.

Submission of documentation to the developers or coordinating committee for appraisal of the adaptation process. This process was supported by the developer, who is currently a lecturer and researcher 
JP3I (Jurnal Pengukuran Psikologi dan Pendidikan Indonesia), I0(2), 202 I

in the Faculty of Psychology in Indonesia, and attended by several graduate students of the Faculty of Psychology in Indonesia. They conducted a review that started from translating to validating the instrument. Furthermore, they also recommend some suggestions and comments regarding the adaptation process based on the Indonesian version.

\section{Results and Discussion}

The mean and standard deviation of the scores of the four dimensions of the TASES Indonesian version are presented in Tables 1 and 3. The score mean and standard deviation after the validation process are reported in Table 1, while Table 2 provides the scores before the TASES Indonesian version validation.

Table 1. Mean and Standard Deviation of TASES after Validation

\begin{tabular}{lcc}
\hline \multicolumn{1}{c}{ Characteristics } & Mean & Std. Deviation \\
\hline Self-Engagement & 3.100 & .418 \\
Self-Oriented Decision-Making & 3.121 & .433 \\
Others-Oriented Problem-Solving & 2.936 & .482 \\
Interpersonal Climate & 3.206 & .445 \\
\hline
\end{tabular}

Table 2. Mean and Standard Deviation of TASES before Validation

\begin{tabular}{lcc}
\hline \multicolumn{1}{c}{ Characteristics } & Mean & Std. Deviation \\
\hline Self-Engagement & 3.100 & .418 \\
Self-Oriented Decision-Making & 3.121 & .433 \\
Others-Oriented Problem-Solving & 2.936 & .482 \\
Interpersonal Climate & 2.991 & .375 \\
\hline
\end{tabular}

As reflected in Table 1 and Table 2, mean and standard deviation scores showed the same results except for the interpersonal climate dimension. Thus, after validation, three items were eliminated from that dimension, and the scores of mean and standard deviation became higher.

Furthermore, Table 3 presented the factor loading of each item and Cronbach's $\alpha$ as a whole and per dimension after validation (containing 25 items). Meanwhile, Table 4 showed the factor loading of each item and Cronbach's $\alpha$ for the whole scale and per dimension before validation, containing 28 items as the original version.

After the validation process, the fit index model of TASES Indonesian version was identified. The indicator of model fit according to CFI, RMSEA, and SRMR, required factor loading score above .32. Further, Table 2 demonstrated that TASES is poor fit with $\mathrm{p}\left(\chi^{2}\right)=.000, \mathrm{CFI}=.784$, TLI $=.761$, AIC $=$ 7979.434, RMSEA $=.078$ [90\% CI .067-.089], SRMR $=.089, \lambda=.337-.762$. Likewise, this scale was reliable with a great index of Cronbach's alpha $(\alpha=.893)$. Moreover, self-engagement, self-oriented decision-making, and others-oriented problem-solving dimensions also obtained the high reliable scores (above .70). However, the interpersonal climate dimension showed the lower reliable score (under .70). 
JP3I (Jurnal Pengukuran Psikologi dan Pendidikan Indonesia), I0(2), 202 I

Table 3. Completely Standardized Factor Loadings of TASES after Validating

\begin{tabular}{ccc}
\hline \multicolumn{1}{c}{ Items/Dimensions } & Factor Loadings $(\boldsymbol{\lambda})$ & Cronbach's $\boldsymbol{\alpha}$ \\
\hline Self-Engagement & & .893 \\
Q1 & .989 & .714 \\
Q2 & .499 & \\
Q6 & .595 & \\
Q7 & .701 & \\
Q9 & .556 & \\
Q16 & .368 & .734 \\
Q23 & .726 & \\
Self-Oriented Decision-Making & .347 & \\
Q3 & .903 & \\
Q13 & .544 & \\
Q17 & .725 & \\
Q18 & .382 & \\
Q20 & .649 & \\
Q21 & .740 & \\
Q22 & .352 & \\
Others-Oriented Problem-Solving & .482 & \\
Q4 & .817 & \\
Q8 & .646 & \\
Q10 & .683 & \\
Q11 & .762 & \\
Q14 & .352 & \\
Q27 & .509 & \\
Q28 & .451 & \\
Interpersonal Climate & .403 & \\
Q5 & 1.030 & \\
Q15 & .357 & \\
Q19 & .337 & \\
Q26 & .512 & \\
\hline
\end{tabular}


JP3I (Jurnal Pengukuran Psikologi dan Pendidikan Indonesia), I0(2), 2021

Table 4. Completely Standardized Factor Loadings of TASES before Validating

\begin{tabular}{|c|c|c|}
\hline Items/Dimensions & Factor Loadings $(\lambda)$ & Cronbach's $\alpha$ \\
\hline & & .886 \\
\hline Self-Engagement & .984 & .714 \\
\hline Q1 & .503 & \\
\hline Q2 & .597 & \\
\hline Q6 & .703 & \\
\hline Q7 & .561 & \\
\hline Q9 & .362 & \\
\hline Q16 & .720 & \\
\hline Q23 & .350 & \\
\hline Self-Oriented Decision-Making & .903 & .734 \\
\hline Q3 & .547 & \\
\hline Q13 & .726 & \\
\hline Q17 & .382 & \\
\hline Q18 & .647 & \\
\hline Q20 & .736 & \\
\hline Q21 & .354 & \\
\hline Q22 & .483 & \\
\hline Others-Oriented Problem-Solving & .822 & .738 \\
\hline Q4 & .650 & \\
\hline Q8 & .685 & \\
\hline Q10 & .762 & \\
\hline Q11 & .358 & \\
\hline Q14 & .508 & \\
\hline Q27 & .448 & \\
\hline Q28 & .401 & \\
\hline Interpersonal Climate & .997 & .513 \\
\hline Q5 & .372 & \\
\hline Q12 & .196 & \\
\hline Q15 & .357 & \\
\hline Q19 & .578 & \\
\hline Q24 & .150 & \\
\hline Q25 & .303 & \\
\hline Q26 & .529 & \\
\hline
\end{tabular}

Table 4 indicated the score of $\mathrm{p}\left(\mathrm{c}^{2}\right)=.000, \mathrm{CFI}=.760, \mathrm{TLI}=.737, \mathrm{AIC}=9139.424, \mathrm{RMSEA}=.075$ [90\% CI .065-.085], SRMR $=.091,1=.150-.762$. Before validation, there were three items indicating low coefficient of factor loading which were $.196, .150$, and .303 in item 12, 24, and 25 respectively. Thus, those three items have been eliminated. In addition, the coefficient of Cronbach's $\alpha$ was $(\alpha=.886)$ as a whole and the coefficient of Cronbach's $\alpha$ per dimension ranged from .513-.738.

Before the TASES Indonesian version involving 166 Indonesian college students (studying at universities in Indonesia and overseas) was validated, it showed poor fit results. The items that have been allocated in four dimensions (i.e., self-engagement, self-oriented decision-making, other-oriented 
problem-solving, and interpersonal climate) declared fit with indices mentioned above except for three items of the interpersonal climate dimension. Therefore, those items have been eliminated.

Subsequently, after TASES Indonesian version was validated, its results showed a good fit with the scores of RMSEA $=.078, \mathrm{CFI}=.784$, TLI $=.761$. Referring to the standard scores of RMSEA, SRMR, CFI, and TLI mentioned by $\mathrm{Hu}$ and Bentler (1999), the measurement is declared to be valid based upon some criteria, CFI $>.95$, RMSEA $<.06$, SRMR $<.08$ (Hu \& Bentler, 1999). Thus, the first results of this measurement indicated poor fit.

$\mathrm{Hu}$ and Bentler (1999) stated that the objective of the cutoff criteria, RMSEA, TLI, and Mc, is to reject populations with a small number of participants. A small population means the sample size is below 250 (Hu \& Bentler, 1999). As in this study, the sample size is < 250; thus, it is not recommended to use the cutoff criteria as a reference for the fit index.

The IC score after the validation process was smaller than the score before validation. This smaller score proves that the parsimony is better for comparing the two models (Akaike, 1974; Yamin \& Kurniawan, 2009). In short, the second model was found to be fit (i.e., parsimonious/adjusted fit measures). Furthermore, Yamin and Kurniawan (2009) stated that RMSEA < .08 is a good fit (i.e., absolute fit measures), and in this current study, we found the RMSEA score $=.078$. Hence, referring to Yamin and Kurniawan (2009), the Indonesian version of TASES fits with RMSEA <.08.

Meanwhile, the incremental/relative fit measures used the TLI (i.e., Tucker-Lewis Index) and CFI (i.e., Comparative Fit Index) score criteria (Yamin \& Kurniawan, 2009). In Yamin and Kurniawan (2009), the provisions of the TLI and CFI scores showed that $.80 \leq \mathrm{TLI} \leq .90$ and $.80 \leq \mathrm{CFI} \leq .90$ are marginal fit. In this study, we found that TLI and CFI scores were .761 and .784, respectively. If the two scores are rounded off, the acquisition of both TLI and CFI scores is .80. Thus, on the incremental/relative fit measures, the Indonesian version of TASES was found to be a marginal fit.

Internal consistency is used to assess that the instrument has a reliable measurement function (Cohen et al., 2013). We applied the coefficient alpha (Anastasi \& Urbina, 2016) developed by Cronbach (1951) to test the internal consistency. The Cronbach's $\alpha$ coefficient of TASES Indonesian version was found higher $(\alpha=.893)$ than the original version $(\alpha=.880$; Sagone $\&$ Caroli, 2014). This coefficient indicated that TASES Indonesian version is proven to have a high consistency level $(\alpha<.70)$ in measuring academic self-efficacy in different participants (in the original version, the participants were Italian college students).

Furthermore, Cronbach's $\alpha$ per dimension are as follow: [1] self-engagement $(\alpha=.714)$, [2] selforiented decision-making ( $\alpha=.734)$, [3] others-oriented problem-solving $(\alpha=.738)$, and [4] interpersonal climate $(\alpha=.536)$. These results show that Cronbach's $\alpha$ coefficient for the dimensions of selfengagement, self-oriented decision-making, and others-oriented problem-solving are accepted $(\alpha<.70)$. However, Cronbach's $\alpha$ coefficient on the interpersonal climate dimension is not accepted $(\alpha>.70)$.

TASES, which fits this Indonesian version, is like the original version developed by Sagone and Caroli (2014), consisting of four dimensions. Some of these dimensions are as follows: [1] Self-engagement still consists of seven items $(1,2,6,7,9,16,23)$; [2] Self-oriented decision-making is represented by seven items as the initial version $(3,13,17,18,20,21,22)$; [3] Others-oriented problem-solving is still in the same seven items $(4,8,10,11,14,27,28)$; and [4] Interpersonal climate which has changed from the initial version by maintaining four items $(5,15,19,26)$.

In this case, self-engagement drives students to concentrate on lectures by participating in lecture activities (Sagone \& Caroli, 2014). This is how they can observe the lecture process, understand the course topic, and ask questions (for instance) to improve their lecture's understanding. 
Self-oriented decision-making refers to how individuals only depend on themselves in the face of an unpleasant lecture process (Sagone \& Caroli, 2014). Even though students choose a study program according to their interests, there are still some cases of students selecting a study program not following their passion and interest (Prabowo et al., 2019). Each of them has their challenges during the lecture periods. These challenges include the ability to manage time, complete lecture assignments, be active in organizational activities, and so on.

It is certainly not easy for students who have to complete multiple college tasks at nearly the same time. But, on the other hand, they are required to accomplish their courses that they are not interested in. In this case, they should have strategies to organize themselves and to overcome the difficulties during the lecture process.

Others-oriented problem-solving is related to the role of the involvement of others (such as friends, lecturers, academic staff, and so on) in solving problems/obstacles experienced related to lectures (Sagone \& Caroli, 2014). In this case, students cannot be separated from several things that hinder the lecture process. Thus, others-oriented problem-solving is seen when students maintain good relationships with friends and establish good communication with lecturers. When they notice something they do not understand, they will ask for an explanation from the lecturer instead of looking for answers by reading the literature by themselves.

The last dimension is the interpersonal climate that focuses on how individuals can cooperate with their friends (Sagone \& Caroli, 2014). The situation where students collaborate in group activities/assignments will make it easier for them to undergo the lecture process, especially in completing lecture assignments.

Self-efficacy, grounded from social cognitive theory by Albert Bandura (Bandura, 1986), is linked to many particular domains such as academic, social, career, clinical, and health areas (Bandura, 1997). In the educational context, when one has higher levels of academic self-efficacy, one tends to be more inspired, motivated, use more strategies (such as self-regulated learning) to achieve more achievements, and experience less tension and anxiety (Barry \& Finney, 2009). In particular, self-efficacy has been extensively studied in academic and social fields with college-aged populations since they are the critical elements of academic life. Therefore, Sagone and Caroli (2014) constructed The Academic Self-Efficacy Scale (TASES) to measure academic self-efficacy.

Future research may consider creating new interpersonal climate dimension items of the TASES Indonesian version and should subsequently analyze them since three items have already been deleted. Therefore, TASES Indonesian version might be a more acceptable fit to assess the academic self-efficacy of Indonesian college students. Furthermore, the following researchers also may conduct comparative research regarding the differences between the academic self-efficacy of rural college students and that of urban college students and how technology can influence their academic self-efficacy. More additional research is needed.

\section{Conclusion}

The original version of the academic self-efficacy scale (TASES) consisted of 30 items at first within four dimensions. Then two items were removed after testing the analysis process, and 28 items remained. This present study attempted to adapt TASES into the Indonesian version using CFA and found that 25 items fit the criteria indices. In contrast, items 12, 24, and 25 did not fit the criteria and were eliminated. Thus, the Indonesian version of TASES also indicates high reliability and fits within four dimensions. In sum, the current version of TASES is a reliable and valid measurement instrument for academic selfefficacy for the Indonesian population. This research process used the Indonesian version of TASES by 
involving Indonesian students as participants. This indicates that, for Indonesian undergraduate and postgraduate student participants, the 25 items from TASES are useful for accessing students' confidence in their academic abilities during pursuing their degree.

\section{Acknowledgment}

We appreciate Dr. Mirra Noor Milla, who provided an opportunity for guiding the process of adapting measurements in the context of cross-cultural adaptations.

\section{References}

Akaike, H. (1974). A new look at the statistical model identification. IEEE Transactions on Automatic Control, 19(6), 716-723. https://doi.org/10.1109/TAC.1974.1100705

Anastasi, A., \& Urbina, S. (2016). Psychological testing (R. Hariono \& Imam, Trans.). Penerbit Indeks (Original work published 1997)

Bandura, A. (1977). Self-efficacy: Toward a unifying theory of behavioural change. Psychological review, 84(2), 191-215. https://doi.org/10.1037/0033-295X.84.2.191

Bandura, A. (1986). Social foundations of thought and action: A social cognitive theory. Prentice Hall.

Bandura, A. (1993). Perceived self-efficacy in cognitive development and functioning. Educational psychologist, 28(2), 117-148. https://doi.org/10.1207/s15326985ep2802_3

Bandura, A. (1997). Self-efficacy: The exercise of control. Freeman.

Barry, C. L., \& Finney, S. J. (2009). Can we feel confident in how we measure college confidence? A psychometric investigation of the college self-efficacy inventory. Measurement and Evaluation in Counseling and Development, 42(3), 197-222. https://doi.org/10.1177/0748175609344095

Beaton, D. E., Bombardier, C., Guillemin, F., \& Ferraz, M. B. (2000). Guidelines for the process of crosscultural adaptation of self-report measures. Spine, 25(24), 3186-3191. https://doi.org/10.1097/00007632-200012150-00014

Bland, J. M., \& Altman, D. G. (1997). Statistics notes: Cronbach's alpha. BMJ, 314(7080), 572. https://doi.org/10.1136/bmj.314.7080.572

Borsa, J. C., Damasio, B. F., \& Bandeira, D. R. (2012). Cross-cultural adaptation and validation of psychological instruments: Some consideration. Paideia (Ribeirão Preto), 22(53). http://dx.doi.org/10.1590/S0103-863X2012000300014

Brown, T. A. (2015). Confirmatory factor analysis for applied research (2nd Edition). Guilford Press.

Cohen, R., J., Swerdlik, M., E., \& Sturman, E., D. (2013). Psychological testing and assessment: An introduction to tests and measurement (8th Ed). Mc-Graw-Hill.

Cozby, P. C., \& Bates, S. C. (2015). Methods in behavioral research. McGraw-Hill Education.

Cronbach, L. J. (1951). Coefficient alpha and the internal structure of tests. psychometrika, 16(3), 297-334. https://doi.org/10.1007/BF02310555

Garett, R., Liu, S. \& Young, S. D. (2017). A longitudinal analysis of stress among incoming college freshmen. Journal of American college health, 65(5), 331-338. https://doi.org/10.1080/07448481.2017.1312413

Gleitman, L., \& Papafragou, A. (2012). Language and thought. In K. J. Holyoak \& R. G. Morrison (Eds.). The oxford handbook of thinking and reasoning. Oxford University Press.

Gore, P. A. (2006). Academic self-efficacy as a predictor of college outcomes: Two incremental validity studies. Journal of career assessment, 14, 92-115. https://doi.org/10.1177/1069072705281367

Graham, D. J., \& Midgley, N. G. (2000). Technical Communication-Graphical Representation of Particle Shape using Triangular Diagrams: An Excel Spreadsheet Method. Earth Surface Processes 
JP3I (Jurnal Pengukuran Psikologi dan Pendidikan Indonesia), I0(2), 2021

and Landforms, 25(13), 1473-1478.

https://doi.org/10.1002/1096-

9837(200012)25:13<1473::AID-ESP158>3.0.CO;2-C

Gravetter, F. J., \& Forzano, L. A. B. (2018). Research methods for the behavioral sciences. Cengage Learning.

Hinton, P. R., McMurray, I., \& Brownlow, C. (2004). SPSS explained. Routledge.

Hu, L. T., \& Bentler, P. M. (1999). Cutoff criteria for fit indexes in covariance structure analysis: Conventional criteria versus new alternatives. Structural equation modeling: a multidisciplinary journal, 6(1), 1-55. https://doi.org/10.1080/10705519909540118

Kementerian Riset, Teknologi, dan Pendidikan Tinggi. (2015). Statistika pendidikan tinggi 2014/2015. Jakarta: Kemenristek Dikti.

King, L. (2017). The science of psychology. McGraw-Hill Education International Edition.

Lacobucci, D. (2010). Structural equations modeling: Fit indices, sample size, and advanced topics. Journal of Consumer Psychology, 20(1), 90-98. https://doi.org/10.1016/j.jcps.2009.09.003

Li, L. K. (2012). A study of the attitude, self-efficacy, effort and academic achievement of CityU students towards research methods and statistics. Discovery-SS Student E-Journal, 1(54), 154-183. Citing internet sources

URL https://pdfs.semanticscholar.org/b0a9/188bb5f66783c09624db8ca7b96922523ab5.pdf.

Little, T. D. (2013). Longitudinal structural equation modeling. Guilford Press.

Lupyan, G. \& Lewis, M. (2019). From words-as-mappings to words-as-cues: the role of language in semantic knowledge. Language, cognition, and neuroscience, 34(10). https://doi.org/10.1080/23273798.2017.1404114

Maulida, A. (2012). Gambaran tingkat depresi pada mahasiswa program sarjana yang melakukan konseling di badan konseling mahasiswa universitas Indonesia. Skripsi, Fakultas Ilmu Keperawatan, Universitas Indonesia.

Midgley, C., Maehr, M. L., Hruda, L.Z., \& Anderman, E. M. (2000). The patterns of adaptive learning scale (PALS) 2000. University of Michigan

Morton, S., Mergler, A., \& Boman, P. (2014). Managing the transition: The role of optimism and selfefficacy for first-year Australian university students. Journal of Psychologists and Counsellors in Schools, 24(1), 90-108. https://doi.org/10.1017/jgc.2013.29.

Muris, P. (2001). A brief questionnaire for measuring self-efficacy in youths. Journal of Psychopathology and Behavioral Assessment, 23(3), 145-149. https://doi.org/10.1023/A:101096111.

Novack, M., \& Goldin-Meadow, S. (2015). Learning from gestures: how our hands change our minds. Educational psychology review, 27(3), 405-412. https://doi.org/10.1007/s10648-015-9325-3

Owens, M., Stevenson, J., Hadwin, J. A., \& Norgate, R. (2012). Anxiety and depression in academic performance: An exploration of the mediating factors of worry and working memory. School Psychology International, 33(4), 433-449. https://doi.org/10.1177/0143034311427433

Pierceall, E. A. \& Keim, M. C. (2007). Stress and coping strategies among community college students. Community college journal of research and practice, 31(9), 703-712. https://doi.org/10.1080/10668920600866579

Pratiwi, P. C., Andayani, T. R., \& Karyanta, N. A. (2012). Perilaku Adiksi Game-online Ditinjau dari Efikasi Diri Akademik dan Keterampilan Sosial pada Remaja di Surakarta. Jurnal Ilmiah Psikologi Candrajiwa, 1(2). Citing internet sources URL http://candrajiwa.psikologi.fk.uns.ac.id/index.php/candrajiwa/article/view/27

Prabowo, W., Yusuf, M., \& Setyowati, R. (2019). Pengambilan keputusan menentukan jurusan kuliah ditinjau dari student self-efficacy dan persepsi terhadap harapan orang tua. Jurnal Psikologi Pendidikan Dan Konseling: Jurnal Kajian Psikologi Pendidikan Dan Bimbingan Konseling, 5(1), 42-48. https://doi.org/10.26858/jppk.v5i1.7460 
Putwain, D., Sander, P., \& Larkin, D. (2013). Academic self-efficacy in study-related skills and behaviours: Relations with learning-related emotions and academic success. British Journal of Educational Psychology, 83(4), 633-650. https://doi.org/10.1111/j.2044-8279.2012.02084.x

Sagone, E., \& De Caroli, M. E. (2014). Locus of control and academic self-efficacy in university students: The effects of Self-concepts. Procedia-Social and Behavioral Sciences, 114, 222-228. https://doi.org/10.1016/j.sbspro.2013.12.689.

Sander, P., \& Sanders, L. (2009). Measuring academic behavioural confidence: the ABC scale revisited. Studies in Higher Education, 34(1), 19-35. https://doi.org/10.1080/03075070802457058

Sharma, B., \& Wavare, R. (2013). Academic stress due to depression among medical and para-medical students in an indian medical college: Health initiatives cross sectional study. Journal of Health Sciences, 3(5), 029-038. Citing internet sources URL https://www.researchgate.net/profile/Balkishan_Sharma/publication/237201322_ACADEMI C_STRESS_DUE_TO_DEPRESSION_AMONG_MEDICAL_AND_PARAMEDICAL_STUDENTS_IN_AN_INDIAN_MEDICAL_COLLEGE_HEALTH_INITIATIVE S_CROSS_SECTIONAL_STUDY/links/0046351bab91e156a1000000/ACADEMIC-STRESSDUE-TO-DEPRESSION-AMONG-MEDICAL-AND-PARA-MEDICAL-STUDENTS-IN-ANINDIAN-MEDICAL-COLLEGE-HEALTH-INITIATIVES-CROSS-SECTIONALSTUDY.pdf.

Solberg, V. S., O'Brien, K., Villareal, P., Kennel, R., \& Davis, B. (1993). Self-efficacy and Hispanic college students: Validation of the college self-efficacy instrument. Hispanic journal of behavioral sciences, 15(1), 80-95. https://doi.org/10.1177/07399863930151004.

Stinebrickner, T., \& Stinebrickner, R. (2012). Learning about academic ability and the college dropout decision. Journal of Labor Economics, 30(4), 707-748. https://doi.org/10.1086/666525

Talar, Y. \& Gozaly, J. (2020). Student retention in Indonesian private university. International journal of evaluation and research in Education (IJERE), 9(3), 486-493. Doi: 10.11591/ijere.v9i3.20582

Tabachnick, B. G., \& Fidell, L. S. (2007). Using multivariate statistics. Allyn \& Bacon/Pearson Education.

Yamin, S., \& Kurniawan, H. (2019). Structural equation modeling: Belajar lebih mudah teknik analisis data kuesioner dengan lisrel-pls. Salemba Infotek. 
JP3I (Jurnal Pengukuran Psikologi dan Pendidikan Indonesia), I0(2), 202 I

Appendix A. The Academic Self-Efficacy Scale of Indonesian Version

\begin{tabular}{cl}
\hline No. & \\
\hline 1 & Q1. Saya dapat menjaga perhatian saya selama dosen mengajar di kelas \\
2 & Q2. Saya dapat membuat strategi yang berguna untuk mempelajari mata kuliah yang belum pernah \\
& dipelajari sebelumnya \\
4 & Q3. Saya dapat bereaksi secukupnya dalam menghadapi suatu kegagalan \\
5 & Q4. Saya mampu mengungkapkan keraguan dan ketidakpastian tentang materi yang disampaikan dosen \\
6 & Q6. Saya dapat mempersiapkan mata kuliah yang diharapkan dalam sebuah program pelatihan \\
7 & Q7. Saya dapat mengaitkan berbagai topik dari berbagai mata kuliah yang berbeda \\
8 & Q8. Saya dapat mengungkapkan ketidaksetujuan saya terhadap ide-ide dosen \\
9 & Q9. Saya mampu belajar tanpa bantuan orang lain \\
10 & Q10. Saya dapat membicarakan berbagai kesulitan dengan dosen-dosen saya \\
11 & Q11. Saya dapat memahami alasan dibalik kegagalan yang saya alami \\
12 & Q13. Saya mampu mengelola situasi yang sulit \\
13 & Q14. Saya dapat meminta bantuan dosen untuk menyelesaikan masalah di Universitas \\
14 & Q15. Saya mampu bekerja sama dalam kegiatan kelompok \\
15 & Q16. Saya dapat berusaha untuk mencapai tujuan yang sudah ditetapkan \\
16 & Q17. Saya dapat menghindar dari situasi yang tidak menyenangkan \\
17 & Q18. Saya mampu membaca situasi dan memilih hal yang terbaik untuk saya \\
18 & Q19. Saya dapat menjadikan cita-cita saya selaras dengan pilihan profesi saya \\
19 & Q20. Saya mampu mengambil keputusan dengan memikirkan resikonya \\
20 & Q21. Saya dapat menghindari pengaruh orang lain dalam pengambilan keputusan di masa yang akan \\
21 & Q22. Saya mampu berusaha dengan baik walau pada mata kuliah yang tidak saya sukai \\
22 & Q23. Saya dapat meminta bantuan orang lain bila mengalami kesulitan \\
23 & Q26. Saya dapat membahas penilaian belajar yang tidak sesuai dengan yang seharusnya saya dapatkan \\
25 & Q27. Saya dapat membangun suasana positif saat menjalin hubungan dengan teman-teman kuliah \\
\hline &
\end{tabular}


JP3I (Jurnal Pengukuran Psikologi dan Pendidikan Indonesia), I0(2), 202 I

Appendix B. Graphical Model for TASES in Indonesian Version with 25 Items

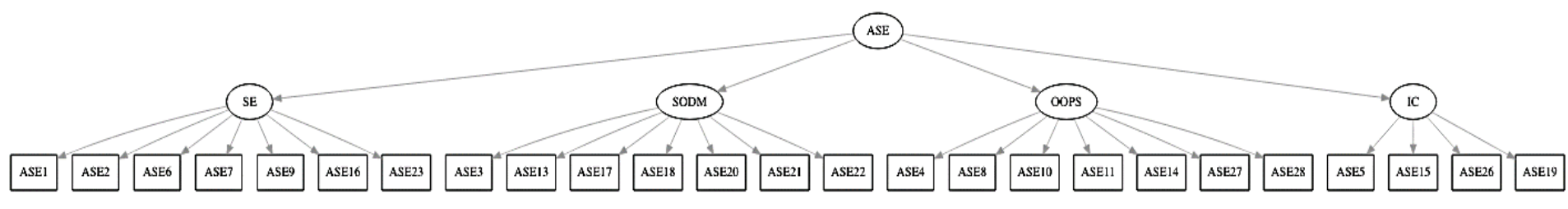

ASE = Academic self-efficacy; SE = Self-engagement; SODM = Self-oriented decision-making; OOPS $=$ Others-oriented problem-solving; $\mathrm{IC}=$ Interpersonal climate 